\title{
Investigating teacher learning from a university programme for Foundation Phase teachers
}

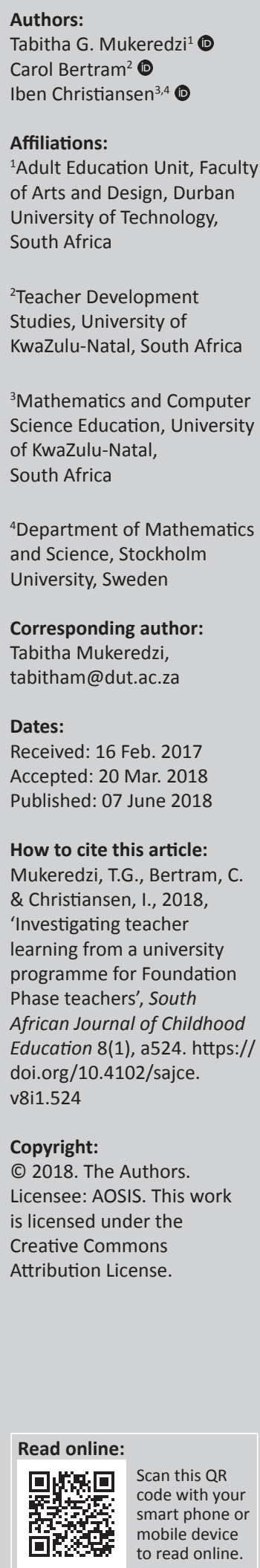

Background: There is a growing focus in South Africa on teachers developing appropriate knowledge, skills and dispositions for teaching to support young learners' development and learning. One such teacher development programme is the Advanced Certificate in Teaching for Foundation Phase teachers, offered by the University of KwaZulu-Natal (UKZN). This research sought to establish the learning of this sample of teachers as this was the first time the programme was offered at this level in South Africa and in UKZN.

Aim: The study investigated the knowledge the teachers said they gained, how they acquired it and ways in which they said learning improved their classroom practices.

Methods: This was a qualitative study. Data were generated from 26 participants through two rounds of focus group interviews in June 2013 and in November 2014. Data were analysed thematically using concepts of accommodation or assimilation, and practical or conceptual knowledge.

Results: Respondents' statements indicated development of a range of practical knowledge about planning and teaching strategies, and conceptual knowledge like child development, creative play, circle of courage and others. Teachers also reported ways in which their classroom practices had improved. However, both institution- and student-related learning barriers emerged during the first semester around programme demands and poor curriculum delivery.

Conclusion: Respondents reported more about acquiring practical than conceptual knowledge and having improved practices in many ways. Participants also reported gaining conceptual knowledge around child development, circle of courage, and learning barriers. They acquired these kinds of knowledge through both assimilation and accommodation.

\section{Introduction and background}

The comparatively poor results of South African children in international, national and even provincial language and mathematics tests at Grade 3, 6 and 9 levels (South African Department of Basic Education 2012; Taylor 2013) have drawn increasing attention to the provision of quality teaching and supply of teachers with appropriate knowledge and skills for teaching Grades R to 3 (Bloch 2009; Fleisch 2008; Green et al. 2011). In an effort to contribute towards the supply of qualified teachers for the Foundation Phase (FP), the University of KwaZulu-Natal launched an Advanced Certificate in Teaching (ACT) FP in January 2013. This was a new parttime programme offered at this level for the first time in South Africa to practising FP teachers who already had a teaching qualification. Thus, the launch of this programme was in response to calls for adequately-trained teachers at this level. The majority of the teachers who enrolled were teaching in rural schools of the KwaZulu-Natal province.

The overall research project aimed to investigate the learning of the ACT FP students in this new programme and did so through a pre-/post-test written by all the enrolled students, classroom observations of three teachers and two focus group interviews exploring the experiences and perceptions of a sample of students. The key questions that this article, which engages only with the focus group interview data, addresses are as follows: (1) what do the ACT FP students say they have learnt through the ACT university-based programme? and (2) what do they imply about the ways in which their learning has affected their practice?

\section{The University of KwaZulu-Natal Advanced Certificate in Teaching Foundation Phase programme}

The ACT FP programme at UKZN was a 128-credit programme, offered through mixed mode delivery to teachers who wanted to obtain a National Qualification Framework (NQF) Level 6 
qualification $^{1}$ (Ebrahim, Verbeek \& Mashiya 2012). Most of these teachers had a National Professional Diploma in Education (NPDE) specialising in FP teaching. The programme duration was two years part-time and students attended classes at three university learning centres in the KwaZulu-Natal province on Saturdays and during school holidays. The programme had the purpose of accrediting teachers or to retrain qualified teachers in a new teaching subject or phase, namely, teaching in the FP. The other purpose of the programme was to staff develop teachers who were teaching in the FP but were either inadequately qualified to teach in that phase or were teaching in FP but qualified to teach in other phases. The programmes aimed to 'enable students to develop disciplinary, pedagogical, practical and situational learning reflexive competences' (University of KwaZulu-Natal ACT FP Programme Template 2012a:2). Teaching in the FP requires specialised Pedagogical Content Knowledge for the FP. Some of these teachers had some teaching qualification but not necessarily for the FP classes. Teacher professional development initiatives in South Africa, among others, speak about the need for qualified teaching personnel in this area of early learning. Hence, the importance of programmes such as these.

To enrol in the programme, students had to be practising teachers with either a 4-year Bachelor of Education degree or a relevant Advanced Diploma or an old Advanced Certificate in Education at Level 6 or a completed Diploma in Education (Level 5) and classroom-based experience in the FP of more than one year. Students who met the second criterion, but were not practising FP teachers, needed to show that they had made the necessary arrangements to access FP classrooms during the programme.

The programme consisted of eight modules which are listed in Figure 1. Students registered for two modules in each semester. The modules were taught on Saturdays by tutors in a range of learning centres. Each module had a learning guide which contained the core content and formative learning activities for self-study.

\section{Professional development and change in teachers' practice}

There has been an increasing number of professional development courses offered to South African teachers since the 1980s, and the democratically-elected government has spent a substantial amount of resources on upgrading teacher qualifications since 1994. Taylor and Vinjevold (1999) noted more than a decade ago that there was a dearth of evidence and impact evaluations of the large number of teacher development programmes offered in South Africa. However, there has been an increase of these studies over the past 15 years.

An in-depth study of secondary school teachers' 'take-up' from the Wits Further Diploma in Education (FDE) in 1996-

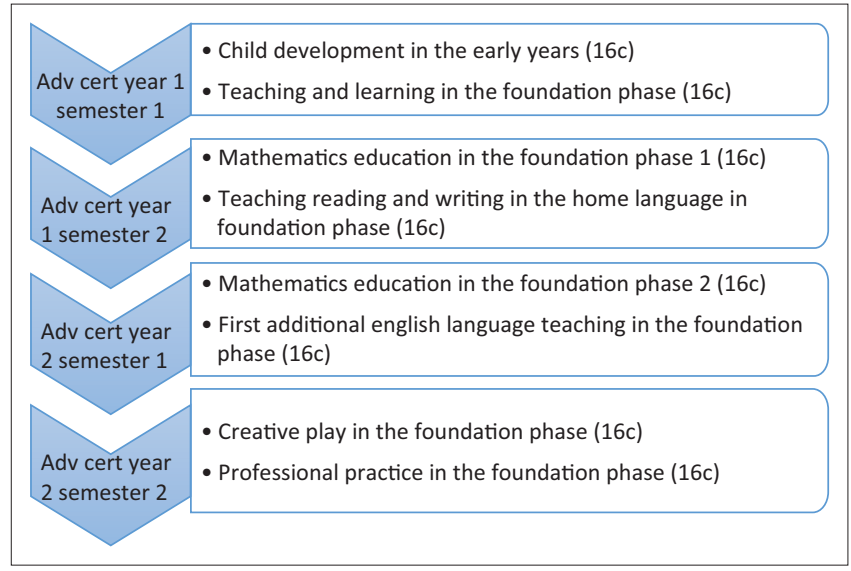

Source: University of KwaZulu-Natal ACT Programme Template 2012 Adv cert; Advanced Certificate.

FIGURE 1: Advanced Certificate in Teaching programme: Module flow chat with allocated credit points.

1998 was one of the first systematic studies in South Africa on what teachers learn from a formal in-service programme (Adler \& Reed 2002). This was a qualitative case study which followed 25 teachers from the programme over three years. It noted that all teachers gained subject content knowledge on the programme (at varying depths) and increased their confidence (p. 149), but this was not always enough to impact their teaching practice. Personal disposition and school context were key factors which influenced teachers' ability to change the quality of their teaching practices.

A recent study of the short courses offered by Western Cape Education Department (Meyer \& Abel 2015) reports findings similar to the Wits FDE study that change in practice is variable and dependent on individual teacher characteristics and their school context. Of 18 teachers, 10 achieved 'third level' outcomes (Harland \& Kinder 1997), which is gaining new information and awareness of new practices. The others achieved 'second level' outcomes, which is gaining new motivation and confidence in their teaching and some basic changes to teaching strategies. Only one teacher was found to have achieved 'first level' outcomes, which is a sustained implementation of new knowledge and skills.

A recent study of the B.Ed. (FP) programme offered in the Northern Cape by Rhodes University argues that this programme has contributed to positive changes in practice at the classroom level (Brown, Wilmot \& Paton Ash 2015). Teachers on this programme indicated that the programme helped them to reflect on their practice and develop both professionally and personally. The study indicates that the teachers appeared to have become more resourceful and creative in their teaching and to develop a deeper understanding of the children. Some of the schools reported evidence of improvements in their learners' Annual National Assessments results across three years that the teachers were enrolled on the part-time programme. Perhaps the success of the programme in changing teachers' practice was influenced by the delivery of the programme which included a field worker to support teachers in their schools. 
There are a large number of studies about the professional development of science and mathematics teachers in South Africa (Adler \& Reed 2002). A recent study has shown that the learners who were taught by teachers who attended a year-long course which developed their mathematics knowledge for teaching achieved higher marks in class tests and exercises than learners taught by teachers who did not attend the course (Pournara et al. 2015).

Thus, what we know about the influence of formal university teacher development programmes in South Africa is that it is difficult for teachers to change their practices in sustained ways, and that this is strongly influenced by teachers' own motivation and knowledge base, and the context of their school (both organisationally and materially). Within mathematics teacher education, there is a strong focus on the importance of developing teachers' knowledge of mathematics for teaching.

\section{Conceptual framework}

There is a general agreement among researchers that two sorts of knowledge are needed for professional practice (Gamble 2009; Knight 2002; Rittle-Johnson \& Schneider 2016; Star \& Gabriel 2013). One type is procedural, practical or 'how to' knowledge, which is the knowledge of the steps required to attain various goals (Rittle-Johnson \& Schneider 2016). In teaching, this practical knowledge includes knowing how to organise group work, how to make learning resources or how to manage a class, but it can also be knowing how to represent an idea or concept in a range of different ways to support student understanding.

The second type is conceptual or declarative knowledge, which is propositional in nature and which includes concrete facts as well as higher-order, abstract knowledge of ideas and principles (Knight 2002). Rittle-Johnson and Schneider (2016) add that knowledge of concepts, including principles, generalisations and definitions, is sometimes also called principled knowledge and is often characterised as knowledge that is rich in relationships between ideas. Thus, practical knowledge is mainly about learning how to do a task and conceptual knowledge is mainly about sensemaking and meaning.

The ACT students in this study were expected to acquire both practical and conceptual knowledge from the programme. We, therefore, analysed their interview responses for whether they referred to practical or conceptual learning (see Table 2).

Illeris (2009) proposes four types of learning: transformative, accommodative, assimilative and cumulative learning. We have drawn on this learning framework in our interpretation of the teachers' interview statements. Cumulative and assimilative learning are referred to by Illeris as learning as addition, while accommodative and transformative learning are referred to as learning as change (2015:37).
Cumulative learning involves acquiring isolated formations that are not part of anything else (Illeris 2009:13). Illeris views this type of learning as one in which an individual learns something without a context of meaning or personal significance which is characterised by mechanisation and only recalled and applied in situations that are mentally similar to the learning context.

Firstly, assimilative learning implies that new knowledge is linked to an existing schema, as it easily fits in with what is already known (Illeris 2009). In other words, this is integrating new information into existing knowledge or cognitive structures without restructuring them. The assimilated learning is characterised by being linked to an existing scheme or pattern in a way that makes it relatively easy to recall and apply when one is mentally oriented towards the field in question (Illeris 2009).

Secondly, accommodative learning occurs when the new knowledge cannot immediately be linked or related to any existing schema (Illeris 2009). This may also be viewed as a change, an adaptation or expansion in the former knowledge structure to make it consistent with a new learning experience. In such cases, there is a conflict between existing schemas and the new information state, and - if the information is not rejected - schemas are adapted to incorporate the new experience or a new schema is developed. Illeris (2009) suggests that the implication is that the learner breaks down (parts of) an existing scheme and transforms it so that the new situation can be accommodated and linked, and a new schema can be formed. This is more demanding than adding a new element to an already existing mental schema as experienced in assimilative learning.

Finally, transformative learning refers to 'any learning involving change in elements of the individual identity' (Illeris 2015:38) - where identity is understood as 'including the combination and interaction between the individual and the social environment' (Illeris 2014:152). This involves several schemas and occurs in situations of profound significance to the learner, and is demanding because it involves identity change (Kitchenham 2008). It thus has links to therapeutic learning and conscientisation. The concept of transformative learning comes from Mezirow (1978) who saw it as changes in how meaning in life is understood and in perceptions of self, often as a result of a disorienting dilemma. Illeris (2014) argues for including affect and social relations on more equal terms with the cognitive, and Kegan (2009) describes it as changes in epistemology. If we were to exemplify transformative learning for teacher education, following Kegan's different stages, it can be where teachers fundamentally change their perception of and feelings about what teaching is, including in relation to the role of schooling in society, and realise this in changes to their practice; it can be where teachers develop an inner authority from which to make judgements about which perceptions of teaching to work from; or it can be coming to a point where contradictory perceptions of learning and teaching can be engaged at the same time. 
However, in this study the interview data that were generated did not show that teachers had experienced transformative and cumulative learning; therefore, we used only the concepts of assimilative and accommodative learning as analysis tools. We hypothesise that it is not possible to infer transformative learning through interview data that we generated as the questions were not designed to focus on identity development.

\section{Methodology}

The population for the study comprised 180 ACT students who enrolled at the beginning of 2013 and completed the FP programme at the end of 2014.

Data were generated through two separate focus group interviews following semi-structured interview schedules. The first round of interviews was held with nine teachers in June 2013, after students had completed two modules (namely, Child Development in the Early Years and Teaching and Learning in the FP). The second round of interviews was conducted in November 2014 with 23 participants after students had just completed the programme. Six of the students participated in both interviews; hence, the total number of participants in this study is 26 . The interviews were conducted by the three authors. The focus group interviews were audio recorded and later transcribed verbatim. Each focus group discussion lasted between 60 and $90 \mathrm{~min}$. This was not a random sample of the entire group, but comprised the students who agreed to participate. Consequently, findings and conclusions drawn cannot be viewed as reflecting learning of all the students on the course, but they provide a snapshot of the learning of the teachers who participated in the study. All nine teachers in the two focus groups in June 2013 were teaching in schools that are located in rural areas. Five of the teachers were Grade R teachers, two were teaching multigrade classes, one was teaching Grade 2 and one was teaching Grade 3. Of the 23 teachers interviewed in November 2014, only two were teaching in schools located in urban settings, and the rest were teaching in rural schools. Eight of these teachers were teaching Grade R, two were teaching multigrade classes, eight were teaching Grade 1, four were teaching Grade 2 and one was teaching Grade 3. Viewed against the demographic details of the entire group of the students registered on the ACT programme in 2013, this is a fair representation of the bigger group of teachers who were enrolled on the programme, namely, that most taught in rural schools and half were Grade $\mathrm{R}$ teachers.

The transcripts were coded for Illeris' types of learning (assimilative and accommodative), as well as practical and conceptual knowledge. We also coded for students' experiences of learning barriers mainly from organisational or institutional learning processes. The first round of coding was carried out by the first author, subjected to scrutiny by the other two authors and revised. One concern in transcribing focus group interviews is that it was not always possible to determine who said what; therefore, we did not code chunks of information that we could not relate to the speakers and relied only on the information whose speakers we were able to identify. Before starting the focus group discussions, we asked all the participants to choose a number that they preferred us to call them with and before giving a response, they would say their number to enable us to link the response to the number. This is how we were able to attach some direct quotations to individual teachers. This of course constitutes a validity concern, but we feel that the resulting analysis still provides a snapshot of the participants' learning experiences.

The three researchers generated the data and worked on the data analysis together and then writing up was done by the first author. The data set was then passed to the other researchers to confirm or identify errors and omissions. They then sent back to the first author for modifications to be made. This process continued until such a time that the three authors felt that the article could be submitted to a journal. This peer debriefing and engagement was meant to enhance trustworthiness.

Before moving onto findings, we provide examples of the coding for the various coding categories.

\section{Coding}

Indicators of the different types of learning and examples taken from interview data are provided in Table 1, and indicators and examples of kinds of knowledge are provided in Table 2.

\section{Ethical considerations}

Participants consented to participate in the research by signing a consent form. The UKZN Higher Degrees and Ethics Committee awarded the ethical clearance for the use of the student data and the interview process.

TABLE 1: Types of learning, indicators for the different types of learning and examples.

\begin{tabular}{|c|c|c|}
\hline Type of learning & Indicators & Examples \\
\hline Cumulative & $\begin{array}{l}\text { Statements that reflect } \\
\text { learning isolated information, } \\
\text { learning by heart }\end{array}$ & $\begin{array}{l}\text { We saw no examples of this } \\
\text { type of learning. }\end{array}$ \\
\hline Assimilation & $\begin{array}{l}\text { Statements that reflect } \\
\text { non-conflictual addition of } \\
\text { new knowledge onto what } \\
\text { the participant knew or did } \\
\text { before }\end{array}$ & $\begin{array}{l}\text { I now know-how important } \\
\text { it is to take children outside. } \\
\text { I now know that there are } \\
\text { some skills that I need to } \\
\text { observe from the child while } \\
\text { they are busy playing outside. } \\
\text { But before I did not know, } \\
\text { it was just for fun. Because } \\
\text { taking them outside was for } \\
\text { fun, but now I know they } \\
\text { learn. }\end{array}$ \\
\hline Accommodation & $\begin{array}{l}\text { Learning that requires a } \\
\text { change, an adaptation or } \\
\text { expansion in the former } \\
\text { knowledge structure to make } \\
\text { it consistent with a new } \\
\text { learning experience. } \\
\text { Statements that reflect } \\
\text { changes in teaching practices }\end{array}$ & $\begin{array}{l}\text { I now allow children time } \\
\text { to try to get answers on their } \\
\text { own before I just gave them } \\
\text { answers. I now know-how } \\
\text { to differentiate and assist } \\
\text { children with problems } \\
\text { and assist all children } \\
\text { who struggle. }\end{array}$ \\
\hline Transformation & $\begin{array}{l}\text { Statements that reflect a shift } \\
\text { in mindset, where teachers } \\
\text { fundamentally change their } \\
\text { perception of or feelings } \\
\text { about what teaching entails }\end{array}$ & $\begin{array}{l}\text { It is not possible to see this } \\
\text { type of learning in interview } \\
\text { data. }\end{array}$ \\
\hline
\end{tabular}


TABLE 2: Types of knowledge, indicators and examples.

\begin{tabular}{|c|c|c|}
\hline Type of knowledge & Indicators & Example \\
\hline Practical knowledge & $\begin{array}{l}\text { Statements that reflect } \\
\text { knowing how to do } \\
\text { something - for example, a } \\
\text { skill or an action that they } \\
\text { are capable of performing, } \\
\text { which may involve being } \\
\text { able to use a particular way } \\
\text { to achieve something. } \\
\text { Skills in carrying out } \\
\text { procedures flexibly, } \\
\text { accurately, efficiently and } \\
\text { appropriately }\end{array}$ & $\begin{array}{l}\text { I can now group the } \\
\text { learners according to their } \\
\text { abilities. } \\
\text { Yes, now I am clear on } \\
\text { how to prepare a learning } \\
\text { programme in my } \\
\text { classroom and how to } \\
\text { teach the young. } \\
\text { I learnt how to arrange my } \\
\text { classroom, what resources } \\
\text { I must use with learners. } \\
\text { llearnt how to teach a } \\
\text { young learner how to read, } \\
\text { how to count using } \\
\text { different methods. }\end{array}$ \\
\hline Conceptual knowledge & $\begin{array}{l}\text { Statements that indicate } \\
\text { that they comprehend } \\
\text { concepts, can apply } \\
\text { concepts or principles of } \\
\text { concepts; that they } \\
\text { comprehend facts and } \\
\text { definitions; can apply } \\
\text { terms related to concepts }\end{array}$ & $\begin{array}{l}\text { I learnt child development, } \\
\text { I learnt how children act at } \\
\text { different levels and stages } \\
\text { of development. } \\
\text { I now know that they are } \\
\text { in preoperational level in } \\
\text { Grade } R \text { and I now treat } \\
\text { them according to their } \\
\text { minds including those } \\
\text { who are less clever. } \\
\text { I learnt about physical } \\
\text { development, intellectual } \\
\text { development and } \\
\text { emotional development; } \\
\text { if I am talking about these } \\
\text { words, I know what I am } \\
\text { talking about. }\end{array}$ \\
\hline
\end{tabular}

\section{Findings}

We present the findings by combining the type of knowledge learnt with the way in which it was learnt.

\section{Practical knowledge}

\section{Practical knowledge learnt through assimilation}

Statements of 17 participants were interpreted as implying gaining practical knowledge through assimilation, and out of these, five participants made more than one statement coded as such, with a total of 30 responses coded for this. As participants were practising teachers, there appeared to have been many instances where they could link new learning with their existing schemas. The following quotes provide examples of how four teachers described what we coded as learning practical knowledge through assimilation. For example, one participant said:

'I was just grouping learners anyhow before, but now I learnt to group learners according to their abilities. So you can focus on that group who are having difficulty maybe to count or recognise number words. That way you can help them according to their abilities. I am now clear how to treat young children from Grade R to Grade 3.' (Teacher 15, Female)

We coded this as assimilation as the teacher did not have to change her mental schema; the new knowledge about ability grouping was assimilated into her existing knowledge.

'Teacher 16 also talked about having gained practical knowledge related to teaching strategies and the new knowledge motivated them: 'the course gave me many new teaching styles to cope with children, I now enjoy my teaching.' (Teacher 16, Female). The new information seemingly fitted in easily with what she already knew or practiced. Other comments made were:
'We were just writing anyhow, not knowing that Foundation Phase teachers have different styles. We learnt that we mustn't write bold, capital letters. If you are colouring, you mustn't colour bold. You must make it light so that learners can see. You mustn't use bright colours, like a pink chart, or use orange colour on the board when writing. How will learners see the orange colour on the board?'(Teacher 19, Female)

'I've learnt that if I am composing a story for Grade R, I write 2 or 3 words, so that it is easy for them to remember. Even the sequencing, of the story and the repetition of words, I mustn't go far; I have to repeat words so that it is easy for them.' (Teacher 8 , Female)

'Another new thing for me is about books, teaching reading, that you need to have a big book and small books, so that if they are here as a group and I am a teacher here, I can open the big book and learners have their small books. The thing in my big book is the same as theirs. It's easy for them when I read, they can see in their small books, that is what ma'am is reading. That way it's easy for them to grasp letters or sounds, because they can see for themselves, what I am reading.' (Teacher 3, Female)

Almost half (17) of the participants appeared to easily engage in describing practical knowledge learnt through assimilation, as they were able to integrate the new information into their existing knowledge or cognitive structures, and they could relate the new learning to the old knowledge without restructuring existing schemas. If the new information had caused inconsistencies, cognitive efforts would have been necessary to reorganise or accommodate the new knowledge and resolve the inconsistencies between old and new learning.

\section{Practical knowledge learnt through accommodation}

Thirteen participants reported on what we interpreted as gaining practical knowledge through accommodation of whom four referred to this type of learning twice, totalling 17 times that practical knowledge was reported as having been gained accommodatively. The following two quotes are illustrations of the kind of practical knowledge that was learnt through accommodation:

'For me what was new is that I must start learners from things that they know. In teaching learners I just came in and say, 'ja, this is this', instead of bringing the knowledge learners know, ask the learner herself, she will tell you, not you a teacher telling the learner what it is. It must come from the learner then go to new stuff, I didn't know that. So now I know that I must drive the learners from known to unknown knowledge, to the right goal.' (Teacher 9, Female)

This comment reflects learning by accommodation as the teacher has had to shift her mental schema so that she now engages learners more actively in the learning process by starting with what they already know. Although this is practical knowledge in the sense that it is a teaching strategy, it is also clear that it is underpinned by some conceptual understanding.

'That is what we have learnt, we have to accommodate [so they] can learn like others. We mustn't ignore [the child who is not coping]. We have to prepare a lesson that will cater for 
them, so that we will take them from Grade $\mathrm{R}$ to the Grade 1 environment...we have to accommodate for all of their levels.' (Teacher 3, Female)

This comment reflects that the teacher has had a mental shift in how she accommodates learners who may be 'slow' or 'fast' and has recognised that she needs to prepare a lesson that will engage diverse learners. Comments made by 13 teachers suggest an adaptation in the former knowledge schema to fit in new learning and some ability to perform different pedagogic actions. This relates to Rittle-Johnson and Schneider's (2016) views that practical knowledge is about skill in carrying out procedures flexibly, accurately, efficiently and appropriately to achieve something.

\section{Conceptual knowledge Conceptual knowledge learnt through assimilation}

Conceptual knowledge is the explicit knowledge of facts and principles (knowing that) (Kennedy 2002). We coded participants' utterances in this way when they indicated learning new ideas or concepts, rather than new ways of doing something. Only six participants made statements which indicated that they had acquired conceptual knowledge through assimilation.

The following quotes illustrate what two of the teachers said:

'Learning styles, we were doing in our classrooms, but we did not know this was linguistic learning style - but now our minds are open. We know when we are talking about linguistic learning style we know what we are talking about. Everything is clear now.' (Teacher 22, Female)

'We always talked about life skills, not knowing that we are in the kinaesthetic. Learners can talk, talk, but when you give them something, and see it, they understand better. We didn't know that there are these [learning] styles, kinaesthetic style, that other learners learn more by touching. They want to touch so that they learn about it. Yes, ACT2 gave us a lot of new knowledge.' (Teacher 14, Female)

The evidence shows that six of the teachers were integrating 'new' conceptual knowledge when they talked about changing the way they view learning (Streule et al. 2006). The teachers were able to integrate these new concepts into their previous thought structures and this new information fitted in easily with what they already knew and practised. Essentially, from our interpretation we believe that they acquired a concept label for what they already did or already knew.

\section{Conceptual knowledge learnt through accommodation}

A greater number of teachers (16) were found as having acquired conceptual knowledge through accommodation. Accommodative learning of conceptual knowledge was coded 33 times in statements by 16 respondents. Some of the comments made in this regard were about the concepts in the child development and creative play modules. Teacher 3 clearly suggests a gap between her previously existing schemas and the new concepts of child development levels ('it was a big animal we didn't know') because these were complex concepts and she needed to change and reorganise her existing schemas in order to accommodate these new concepts:

'These new terms; equilibrium, synergy, accommodation, assimilation, I didn't know them, it opened up our minds. I know now that I am doing this, these learners are at preoperational level. ... I must take them to stage of assimilation so that they can be able to accommodate. Now I know it even if you wake me up in my bed, I can tell you, but at first it was a 'big animal' we didn't know.' (Teacher 3, Female)

'The child development module was the best thing for me. I learnt new things like, scaffolding, ooh, scaffolding learners with learning barriers who can't write, who can't read. To identify those learning barriers, I learnt a lot.' (Teacher 5, Female)

'I learnt a lot from creative play and professional practice. I didn't know-how to plan for a creative play activity to suit children's developmental stage, which has objectives. I now know that it helps to identify learners' learning problems and also their progress.' (Teacher 10, Female)

'I learnt that teaching resources and activities should suit Grade and developmental stage, and should accommodate all learners. Fast learners are given more activities to keep them occupied.' (Teacher 6, Female)

The 'Circle of courage' is a model of working with children's needs that was taught in the module on child development. It proposes that the need to belong and be loved is essential to self-esteem and cognitive development. Thus, it is essential for teachers to establish relationships of trust and respect with their learners. The module argued that many learners have 'broken spirits' that cause them to behave in unproductive and disruptive ways. The module exposed teachers to a range of strategies where they could 'amend' the spirit of their learners by giving positive encouragement and recognising their strengths and help them develop problem-solving strategies and selfdiscipline. Teacher 11 talks about how this way of seeing children's behaviour was completely new for her, and she needed to change her existing schema about children's behaviours:

'I didn't know this thing about the circle of courage. I now understand behaviour of children, they come with different behaviour. ... previously teachers would just take a stick ... but I now understand that if a child behaves like this I must amend their spirit, to amend the behaviour of that child. We gained a lot.' (Teacher 11, Female)

This teacher noted that she had acquired new conceptual knowledge and is also able to articulate what that knowledge might mean for her practice. She makes inferences from the concepts and talks about the possible implications for her own practice. Teacher 11 notes that her understanding of the 'circle of courage' means that she should not just automatically 'take a stick' to a child who is misbehaving. 


\section{How the learning influenced their practice?}

Nineteen of the participants reported that the learning had improved their classroom practices. Four teachers made reference to improved practice more than once, thereby making a total of 24 occurrences of this. Some experienced improved ways in which they were now planning for lessons, introducing learner activities and handling group work:

'In planning, that knowledge changed me a lot, the way I am now planing at school. Before, I was just planning 'nje', now I know the objective of planning this. What I want learners to gain is not just planning. I plan asking myself what I want my learners to learn. Why I'm doing this. I put time that I want this to be finished. ... my learners to be able to understand this by this time, the methods I am going to use. I am now able to change; if this method doesn't work, then I must change to this method so that my learners grasp the knowledge that I want them to learn.' (Teacher 8, Female)

Comments by Teacher 8 suggest critical self-examination and both reflexion and reflection-in-practice. Reflexion here represents looking 'inward' inside oneself during the selfexamination, while reflection implies standing 'outside' the action and analysing one's experiences, and reflection-in practice involves thinking about the action while performing the action and taking appropriate measures (Mukeredzi 2015):
'In introducing the task now, I used to just introduce a letter, but now I know I must first ask learners the letter, what they already know and make them see the difference with the letter that I am going to introduce. For example, if I want to introduce $q$ my learners know $p$ and if I write $q$ they say it is $p$ and that's maybe where I make the difference with them, 'no, this is $\mathrm{p}$, we are going to learn $\mathrm{q}^{\prime}$. There is a difference between $\mathrm{p}$ and $\mathrm{q}$.' (Teacher 7, Female)

Teacher 7 talks about moving learners from what they know to new learning. Leading learners from 'known to unknown' is regarded as a practice that is particularly useful with young learners as it promotes thinking and observation, providing more scope for students' participation as learning becomes easy and permanent and develops their selfconfidence (Campbell \& Campbell 2008). Other participants reported improvements about handling group work:

'Yes, I also learnt the importance of child grouping. Before, I would just look around, and not help them, but I just look around assessing whether they are doing or not, without looking at those who don't know, only clever ones. But now I sit with them, it's very important to sit with them at the table. I allow learners time to struggle with the problem, not just help them with answers. That's what I do now with all my learners.' (Teacher 10, Female)

'Another thing that I also learnt is that if a child has got a problem with work, I mustn't give them the answer now, now, now. I must ask questions that lead him to get answers. Like during activity, perhaps the other group has finished, the other has got a problem, what must I do with that struggling group? I must ask them questions about what they are doing so that they get the answer. I mustn't tell them the answer, but give them questions that lead them to the answer. I never allowed my learners time to think. Now I allow them time to struggle with a problem as a group, to work it out on their own, asking questions. Before, I just gave them answers, I just helped them.' (Teacher 11, Female)

Both Teachers 10 and 11 said that they learnt a new approach for monitoring group work, scaffolding learning and encouraging learners to think, including learners who are slow to master, allowing learners some time to find answers and attending to all learners as opposed to previous practices where attention was only directed towards higher achieving learners and answers were immediately provided.

Many participants also acknowledged gaining practical knowledge and improving their practice around learning through play. To illustrate, the following comments were made:

'I never allowed learners to play and did not have a play pod corner in my classroom. This year was my first time to allow learners to play because of the knowledge I gained from the university. Now I will continue with this practice because some learners have barriers but when they play they learn from each other.' (Teacher 9, Female)

I am the one who always said, 'Shut up, be quiet and put your finger on your mouth!' So now I know that a talkative class is very effective because most of learners are afraid to talk one by one, but when they are in a group they share ideas, so I allow them to talk. (Teacher 19, Female)

The above extracts suggest some changes in teaching strategies as teachers seemingly developed an understanding of the value of learning through play. This kind of impolite teacher talk 'shut up' to stop FP children from talking portrays an impolite and harsh approach to classroom management and learner discipline, which may develop fear in these young learners as opposed to teacher respect. The way they express their previous behaviour suggests some shift in basic premises of teacher's thought, feelings and classroom practice actions. It is through changes in the frame of reference that comprises habits of mind and meaning perspectives, which leads to a change in practice (Kitchenham 2008).

\section{Barriers to learning}

Illeris (2009) defines barriers to learning as mislearning which occurs when most of the intended learning does not take place, is incomplete or distorted because of miscomprehensions, insufficient concentration, limited prior learning or resources, etc. Barriers may be external/situational or internal/ dispositional (Falasca 2011). She defines external barriers as 'influences external to the individual or at least beyond the individual's control', whereas internal barriers often reflect personal attitudes. In this study, 13 participants reported external barriers emanating from organisational or institutional learning processes, citing too much work and too little time to complete assessments, lack or limited preparation for lectures by lecturers, ineffective lecture delivery, assessments and feedback, and complex language adopted by some lecturers, as some of the sources of external barriers. 
Although participants gained both practical and conceptual knowledge through the programme, they opined that their learning was hindered by some barriers. Thirteen participants reported external barriers to learning, particularly too much work which prohibited reading and reflection. For example, one teacher commented that:

'The assignments, we didn't get enough time before the assignment. We just came for the first session and then the assignment. We could not meet with our tutor and explain it because we did not understand it, that was the big problem. Time for the assignment was little, there was too much work; work book activities, tool kit then the assignment in two weeks. There was not time to read or think, just scanning, the headings and rushing.' (Teacher 4, Female)

Other participants highlighted barriers that were related to the tutors. Teachers 7 and 8 made the following comments:
'The tutor was always unprepared for class. She came and sat then read the guide... She didn't mark workbook activities or toolkits presentations, on the last day she started asking for our workbooks and toolkits.' (Teacher 7, Female)
'Her standard is high, so when she teaches, it's like she is teaching people who know everything, but we don't know anything ... the way she speaks, we don't hear because English is her mother tongue; so when she speaks, you can't hear what she says.' (Teacher 8 , Female)

Assessment is a key component of learning which often has a powerful impact on students' learning. When students see how they are doing, they can determine whether or not they understand course material which may motivate them or push them to begin to work harder. From the comments, the teachers experienced that this tutor was not concerned about any of these aspects, and thus did not support, but appeared to hinder the students' learning. There were also instances where the teachers identified the tutor's role as enabling and not hindering their learning. For example: 'It becomes easier because she explains everything clearly for us to understand.' (Teacher 6, Female).

Some respondents noted that they had formed their own study group to help each other understand the child development module. One teacher noted that the $\mathrm{Gr} R$ teachers had to help those who are teaching Grades 2 and 3 as:

'they have no idea of what a small child is doing... what you are going to look for in the work of a small child. It was too difficult for the Grades 2 and 3 teachers, really.' (Teacher 15, Female)

Three teachers made reference to internal barriers to learning that were located within themselves. 'I don't have a child. I find it difficult when people are talking about raising a child' (Teacher 4). Other internal barriers were around mastery of child development module content as pointed by Teacher 3: ' $\ldots$ the child development module is very difficult for us. It is like a B.Ed. module, it is too deep for us' (Teacher 3). This would be supported by data that we collected from the teacher tests which the cohort of teachers wrote when they enrolled in the module (February 2013) and when they completed (October 2014). The non-response to many of the test questions showed that at least 30\% of teachers did not understand the questions (Bertram, Christiansen \& Mukeredzi 2015), and thus would have found some of the text in the learning guide difficult to understand.

\section{Discussion}

The study investigated what 26 of the 180 teachers say about their learning from the ACT FP programme. Hence, findings cannot be assumed to represent the full class of students on the programme. This section first discusses the kinds of knowledge respondents reported they gained from the programme and how the knowledge was acquired. We then discuss the ways in which the teachers reported the learning influenced their practice. We conclude the section by discussing learning barriers reported by participants. Within the discussions, implications are also included.

\section{Kinds of knowledge gained and the ways through which it was acquired}

Generally, participants in this study reported that they had benefitted from the programme and described the new knowledge gained as 'eye-opening'. Data indicate that participants gained both practical and conceptual knowledge through assimilation and accommodation, and the number of mentions of each type of knowledge was not greatly different. Teachers did not talk about learning that could be coded as cumulative and it is likely not possible to infer transformative learning from interview data. Respondents also reported some changes in their practices as a result of their learning from the ACT programme.

The participants mentioned learning practical knowledge 45 times, 28 times assimilatively and 17 times accommodatively. Assimilative and accommodative learning of conceptual knowledge was mentioned 39 times ( 6 by assimilation and 33 by accommodation).

As these participants were practising teachers, who had just completed an NPDE, we might assume that they already possessed a substantial amount of practical knowledge for teaching. However, they said that they learnt new strategies, such as teaching for a diverse range of learners in the class, using different strategies to work with the reasons why a child might be misbehaving and thinking more systematically about how to group learners. Participants highlighted improved knowledge about handling group work, creative play, scaffolding instruction and many other lesson delivery aspects.

What seems significant about this practical knowledge is that it is informed by some understanding of the practice rather than just the implementing of a technique. Thus, we might say that these teachers are developing some kind of professional judgement, as their 'know-how' is informed by some conceptual understanding. 
That said, teachers also noted that they had learnt new practical ways of doing things that were not necessarily informed by understanding, such as using a 'big book' when reading to learners and making sure that the writing on their posters was legible.

The ACT programme was intended to deepen teachers' subject matter knowledge and to equip them with pedagogical, practical and situational knowledge and reflexive skills for teaching Grades $\mathrm{R}$ to 3 (Ebrahim et al. 2012). In our review of the informal assessment tasks in the eight learning guides, we found that there were more tasks that foregrounded the teacher's practice-based context than that foregrounded the concept of study (Christiansen, Bertram \& Mukeredzi, forthcoming). This suggests that the majority of informal assessment tasks were application tasks which required the students to do something with the concepts, rather than engage with the concept on its own terms, or were tasks that did not engage with conceptual knowledge at all. In addition, the modules had a stronger focus on practical and pedagogical knowledge than on subject matter knowledge and conceptual knowledge. It was only the second maths module which focused specifically on developing teachers' own content knowledge, and as such, the majority of tasks assessing the maths content knowledge.

The first interview took place after teachers had completed the child development module and the teaching and learning module. Thus, it is not surprising that the teachers mentioned that they had learnt concepts such as child development (stages of development, physical, intellectual and emotional development), an awareness that their learners were in the preoperational level, creative play, circle of courage, amending spirit, learning barriers and their identification and Piaget's cognitive concepts such as synergy, equilibration, assimilation and accommodation, including the application of these concepts in their teaching. Identification and generation of examples of the concepts including application of the terms that represent those concepts are some of the ways in which students demonstrate conceptual understanding (Rittle-Johnson \& Schneider 2016; Star \& Gabriel 2013). While talking about these concepts and how they applied them seems to imply that these teachers had somewhat mastered them, we cannot really say this theoretical understanding of module concepts adequately addresses learning about child development as there was no further evidence from the data which reflected such mastery.

The second interview took place at the end of the whole programme, after students had completed the two final modules, which were about creative play and professional practice. Teachers did not speak very much about their learning from the two mathematics and two literacy modules, which were offered in their second and third semesters.

Changes in their classroom practice as a result of the learning were reported 23 times by 16 participants. While participants expressed behavioural changes in their practice, this is inadequate for it to be viewed as transformative learning
(Illeris 2009; Kitchenham 2008) as no lessons were observed at the beginning or end of the programme, and even if a change in practice was observed, this does not necessarily mean a change in identity. Transformative learning is about 'perspective transformation' involving three dimensions: psychological (changes in understanding of the self), convictional (revision of belief systems) and behavioural (changes in practice/lifestyle) (Illeris 2009; Kitchenham 2008). The first two of these dimensions could be interrogated through an interview but not the third one. Many teachers indicated that they had changed their beliefs, particularly in terms of their understanding of the child. They said that they now knew that the child needs to have time to play, time to talk and be given the opportunity to hook new knowledge onto what he or she already knows.

\section{Conclusion}

The article has reported on the learning of 26 teachers enrolled on the ACT FP formal programme in 2013 and 2014. The study investigated what knowledge the teachers said that they gained, how they acquired it as well as the ways in which teachers said the learning improved their classroom practices. Data suggest that respondents spoke more about acquiring practical than conceptual knowledge. Participants also reported having improved their practices in a variety of ways. Practical knowledge acquired included planning and teaching strategies, particularly handling group work, learning through play, learning barriers and diversity, and teaching reading. The conceptual knowledge learnt included child development stages, creative play, circle of courage, learning barriers and their identification as well as some cognitive concepts such as equilibration, assimilation and accommodation including their application in teaching. Participants reported that they acquired these kinds of knowledge through what we interpreted as both assimilation and accommodation. Participants further cited improvements in their practice related to lesson preparation and delivery like ability grouping of learners, allowing learners to play and learn, scaffolding learning and teaching learners from what they know to the new information. Teachers also experienced external barriers during the first semester of their studies emanating from the amount of work they were expected to do, poor preparation for lectures by tutors, lack of assessment and the high level of language used by some tutors during lectures. A few students found the content of some modules difficult to comprehend, but through tutorial support from their tutors which facilitated production of more mental energy to keep them going, eventually the content became manageable. This research was carried out to establish the learning of this sample of teachers as this was the first time the programme was offered at this level in South Africa and in the UKZN. While we acknowledge the limitations of our study, the article makes an attempt in contributing to debates on FP teacher learning. In as much as evidence from the data seems to suggest that participants experienced some changes in their practice, which included foregrounding lesson objectives in planning, adopting ability grouping, allowing learners to play and learn, scaffolding 
instruction and teaching learners from 'known' to 'unknown', given that these teachers had previous qualifications, we cannot really confirm that they gained this from the programme. Also because of the methodological limitations related to sampling design and lack of triangulation of data, as well as the self-reported nature of the interview data, these findings cannot be conclusive.

\section{Acknowledgements}

The authors would like to acknowledge the UKZN Teaching and Learning Office for funding the larger project which investigated the knowledge bases of all FP teachers on the ACT FP programme, in which this small research was a strand.

\section{Competing interests}

The authors declare that they have no financial or personal relationships which may have inappropriately influenced them in writing this article.

\section{Authors' contributions}

All authors equally contributed towards the production of the article. After we analysed the data together, T.G.M. the article leader then developed the initial draft and send it to the two colleagues C. B. and I. C. for their input in making conceptual corrections and editing. When comments were received from the Journal, T.G. addressed them first and then sent to C. B. and I.C. for their input and finally T.G. would submit the final copy to the Journal as she was the corresponding author.

\section{References}

Adler, J. \& Reed, Y., 2002, Challenges of teacher development: An investigation of takeup in South Africa, van Schaik, Pretoria.

Bertram, C., Christiansen, I. \& Mukeredzi, T.G., 2015, 'Exploring the complexities of describing foundation phase teachers' professional knowledge base', South African Journal of Childhood Education 5, 169-190. https://doi.org/10.4102/ sajce.v5i1.355

Bloch, G., 2009, The toxic mix: What's wrong with South Africa's schools and how to fix it, Tafelberg, Cape Town.

Brown, B., Wilmot, D. \& Paton Ash, M., 2015, 'Stories of change: The case of a foundation phase teacher professional development programme', South African Journal of Childhood Education 5(1), 191-209. https://doi.org/10.4102/sajce. v5i1.356

Campbell, L. \& Campbell, B., 2008, 'Beginning with what students know: The role of prior knowledge in learning', in L. Campbell \& B. Campbell (eds.), Mindful learning: 101 proven strategies for student and teacher success, pp 7-27,Corwin Press, Thousand Oaks, CA.
Christiansen, I., Bertram, C. \& Mukeredzi, T.G., forthcoming, 'Contexts and concepts: Analysing learning tasks in a Foundation Phase teacher education programme in South Africa', Asia-Pacific Journal of Teacher Education, https://doi.org/10.1080/ South Africa', Asia-Pacific

Ebrahim, H.B., Verbeek, D.C. \& Mashiya, N., 2012, 'Enabling roles to reclaim teacher agency: Insights from the Advanced Certificate in Teaching (Foundation Phase)', Perspectives in Education 29(4), 58-65.

Fleisch, B., 2008, Primary education in crisis: Why South African schoolchildren underachieve in reading and mathematics, Juta, Pretoria.

Gamble, J., 2009, The relation between knowledge and practice in curriculum and assessment, A concept paper commissioned by Umalusi, Umalusi, Pretoria.

Green, W., Parker, D., Deacon, R. \& Hall, G., 2011, 'Foundation phase teacher provision by public higher education institutions in South Africa', South African Journal of Childhood Education 1(1), 109-121. https://doi.org/10.4102/sajce.v1i1.80

Harland, J. \& Kinder, K., 1997, 'Teachers' continuing professional development: Framing a model of outcomes', Journal of In-Service Education 23, 71-84. https:// doi.org/10.1080/13674589700200005

Illeris, K., 2009, Contemporary theories of learning, Routledge, London.

Illeris, K., 2014, 'Transformative learning and identity', Journal of Transformative Education 12(2), 148-163. https://doi.org/10.1177/1541344614548423jtd. sagepub.com

Illeris, K., 2015, 'The development of a comprehensive and coherent theory of learning', European Journal of Education 50(1), 2015. https://doi.org/10.1111/ ejed.12103

Kegan, R., 2009, 'What "Form" transforms?: A constructive-Developmental approach to transformative learning', in K. Illeris (ed.), Contemporary theories of learning: Learning theorists - In their own words, pp. 35-542, Routledge, Abingdon, United Kingdom.

Kennedy, M.M., 2002, 'Knowledge and teaching', Teachers and Teaching 8(3), 355370. https://doi.org/10.1080/135406002100000495

Kitchenham, A., 2008, 'The evolution of John Mezirow's transformative learning theory', Journal of Transformative Education 6(2), 104-123. https://doi.org/ $10.1177 / 1541344608322678$

Knight, P., 2002, 'A systemic approach to professional development: Learning as practice', Teaching and Teacher Education 18(2002), 229-241. https://doi.org/ 10.1016/S0742-051X(01)00066-X

Meyer, S. \& Abel, L., 2015, 'Hastening slowly: Insights about teacher development from an evaluation of courses at the WCED's Cape Teaching and Leadership Institute', Journal of Education 61, 116-146.

Mezirow, J., 1978, 'Perspective transformation', Adult Education Quarterly 28(2), 100110. https://doi.org/10.1177/074171367802800202

Mukeredzi, T.G., 2015, 'Creating space for pre-service teacher professional development during practicum: A teacher educator's self-study', Australian Journal of Teacher Education 40(2), 125-145.

Pournara, C., Hodgen, J., Adler, J. \& Pillay, V., 2015, 'Can improving teachers' knowledge of mathematics lead to gains in learners' attainment in Mathematics?', South African Journal of Education 35(3), 1-10. https://doi.org/10.15700/saje. v35n3a1083

Rittle-Johnson, B. \& Schneider, M., 2016, 'Developing conceptual and procedural knowledge of mathematics', in R. Cohen Kadosh \& A. Dowker (eds.), Oxford handbook of numerical cognition, pp. 1-22, Oxford University Press, Oxford, England.

South Africa Department of Basic Education, 2012, Report on the Annual National Assessments 2012, Department of Basic Education, Pretoria.

Star, J.R. \& Gabriel, J.S., 2013, 'Procedural and conceptual knowledge: Exploring the gap between knowledge type and knowledge quality', Canadian Journal of Science, Mathematics, and Technology Education 13(2), 169-181. https://doi.org/ 10.1080/14926156.2013.784828

Taylor, A., 2013, Reconfiguring the natures of childhood, Routledge, London.

Taylor, N. \& Vinjevold, P. (eds.), 1999, Getting learning right. Report of the President's Education Initiative Research Project, Joint Education Trust, Johannesburg.

University of Kwazulu-Natal, 2012a, Advanced Certificate in Teaching Foundation Phase Programme Template, UKZN School of Education, Pietermaritzburg. 